\title{
The pursuit of pleasurable women in the war-ridden city of Butembo, eastern DR Congo*
}

\author{
KRISTIEN GEENEN \\ Universiteit Gent, Plateaustraat 22, Vakgroep Architectuur en \\ Stedenbouw, 9ooo Gent-Ghent University, Belgium \\ Email: kristien.geenen@ugent.be
}

A B S T R A C T

In this article, I map out spaces of social encounters and elaborate upon the once openly exposed but now hidden nightlife of Butembo, in eastern Congo. I explore what moves the people of Butembo, where they go to have fun, and what 'fun' means in a war-torn place. The main focus lies on the city's countless cabarets, as these seemed the places where people mostly met. A cabaret is a private dwelling where a single woman offers home-brewed alcohol and sexual services alike. Usually, a cabaret bears no signage at all, so from the outside, it is hard to discern from an ordinary house. Yet, their sheer invisibility stands in sharp contrast to their major importance. As I proceed through the article, it becomes clear that these obscure cabarets are spaces of sociability with an undeniable importance that contribute to the functioning of the city in many respects.

\section{N T R O D U C T I O N}

Butembo is a city in the very east of the Democratic Republic of Congo, close to the Ugandan border. It is an economic hub of major importance to the area, being the hometown of the notorious Nande traders - the dominant ethnic group of the city-whose trading movements today ramify as far as Dubai, Jakarta and Guangzhou. Both the vicinity of a transnational border and the on-going warfare catalysed the expansion

* Fieldwork was carried out in 2008 and 2009, funded by FWO and hosted by IARA, University of Leuven. I wish to thank the anonymous reviewers for their insightful comments. I also warmly thank Nancy Rose Hunt and Joe Trapido for their continuous support and encouragements. 
of the trading business of these local Big Men (Vwakyanakazi 1982, 1991; MacGaffey 1987; Raeymaekers 2007, 2014; Geenen 2010, 2012). Indeed, Butembo lies right in the middle of a region that has been war-stricken for over a decade. When Mzee Kabila, backed by foreign allies Uganda and Rwanda, entered Congo in 1996 to topple president Mobutu, "[t]wo national "wars of liberation" quickly followed, both rooted in the Kivus' convoluted mixture of communal violence, political machination, raw sensitivity about borders and contested national identities, the freeze/thaw, on-again off-again actions of aid, and, not least, the enormous mineral and agricultural wealth of the provinces' (Jackson 2002: 520).

To academic literature, the Kivu provides a classic example of the established 'regional traditions of ethnographic writing' (Fardon 1990). The area virtually equals warfare, and most scholars who head for eastern Congo bury themselves in the protruded state of war. They are mainly political analysts, and have written seminal works in an attempt to untangle the complex geopolitical picture (amongst many others: Jackson 2002, 2006; Emizet 2003; Vlassenroot \& Raeymaekers 2004; Reyntjens 2009; Titeca 2009; Raeymaekers 2014). Journalists show an interest in the area too, not deterred by the violence in the Kivu, quite the contrary. However, often the more deeply felt human experience of war is not fully considered. Hoffman (2003: 9) explicitly makes a plea for frontline research, stating there is a need of 'a more thorough ethnography of violence', in particular because current journalists in warzones are usually 'embedded', and this turns out war correspondents 'whose knowledge of local contexts is limited and whose coverage is therefore formulaic'. Today, it is up to scholars to fill in this gap, and anthropologists with their participant observation-method can deliver a meaningful contribution and bring in fresh insights, as Luca Jourdan (2005: 188) states. Others go behind the frontline, and focus upon the population instead of on the armed forces directly involved in the conflict.

With this article, I join the scholars who examine the social impact that this political turmoil has on the population and how this protracted state of violence and insecurity is experienced. However, I approach the issue from a completely different angle. Instead of exploring human suffering, I look for traces of joy and cheerfulness. During fieldwork, which was carried out during 18 months between 2008 and 2009, I tried to map out where the people of this war-ridden area go to have some fun, and what 'fun' actually means in such a context.

Butembo is an unusual city, very different from its neighbouring cities Beni and Goma, which are more cosmopolitan and bustling. A 
newcomer faces the hardest time finding out where Bubolais, as the inhabitants are called, fulfil basic needs such as meeting one another to have a chat or a drink. At first sight, the only spaces of sociability appear to be weddings and funerals. There is no glimpse of the renowned Congolese ambiance in Butembo, 'a term that evokes music, beer, seduction, romance and folly' (Trapido 2010: 122) and an atmosphere that is all over the capital Kinshasa (Biaya 1996; MacGaffey \& BazenguissaGanga 2000: 153). There are no outward signs such as beer advertisements or alluring music to show passers-by where the bars or similar places are. On top of that, the streets are virtually empty after nightfall, as the city is devoid of electric power and the darkness turns a walk in the streets into an insecure venture. Throughout history, there have been some particularly violent outbursts in the city, moments when Bubolais came face to face with political turmoil and death. Violence has left the Bubolais deeply marked, and it has seriously affected social life, dimming the metaphorical bright lights of the city.

In brief, as the streets look completely deserted, at first glance nothing really happens in Butembo after nightfall. Consequently, it took a considerable amount of time before I found out where people had fun, where girls met their future boyfriends or where recent immigrants went to mingle in their new surroundings. These favoured hangouts turned out to be the cabarets, private dwellings where a single woman offers drinks as well as sexual services in an intimate and homelike atmosphere. Once I had 'discovered' these cabarets, I started hanging out in there too, and chatted with anyone willing. At first, I felt uncomfortable and awkward whenever I questioned Bubolais about their ways of pursuing pleasure, fully aware of the misfortunes they went through for over a decade. The violence, the cruelties, the lawlessness, the political instability, it all seemed so much more important. However, the extent of these 'hidden' spaces indicated that this was a vital aspect of Bubolais life too. Getting loaded really did matter. More so, as I soon found out, it mattered not just in spite of, but because of the harsh times. People often expressed their need to drink. Once I was acquainted with the sites where Bubolais go to enjoy the company of friends and drinks, it raised a series of questions. Who are these women running a cabaret? Why did the encounters in cabarets have to take place in secret? And how secret was secret if everybody really knew what was going on?

In this article, I explore the importance of the cabarets, not only to the clients who go there to relax and 'have fun', but particularly to the cabaret owners whose voices will be heard throughout the text. To 
these single, divorced or widowed women, running a cabaret is a means of empowerment; they skilfully answer to the clients' need to drift off for a while. Cabarets are ambiguous places throughout, run by contradictory dynamics with opposing features. They are important and widespread, but invisible and hard to detect. They are places where sexual services are offered, but these are never mentioned out loud. They are officially forbidden, but the authorities shut their eyes. They are also places where danger and pleasure meet. More importantly, they make up the underground of the city, but these thriving sites are inextricably bound up with whatever goes on in the open. I will first explore what exactly happens in these cabarets, and how they function. Next, I outline some of the practices in more detail, as the use of a metaphorical language to mask what is going on, and the connectedness to the world of the healers. Finally, I offer a close look at the lives of the women who run a cabaret. But first, I will briefly elucidate social life in Butembo.

Of course, there are other places than cabarets to go and socialise, and regrettably to any newcomer in town - they are pretty hard to find as well, all of them being disguised as something else. The totality of Butembo's spaces of sociability can be hierarchically, according to accessibility and visibility, arranged as follows: there are some rather fancy hotels, such as Auberge and Hotel Butembo, which are announced by huge billboards. These are the exclusive domain of the town's notables, a bunch of expats and the occasional tourist. Then there are a few nightclubs, such as Miami or Tamtam, whose entrances are illuminated spots in the darkness, inevitably accompanied by the monotonous hum of a generator. These are genuine seventies discos where the prices are kept as steep as the Congolese music is played loud. More accessible are the cafetarias, places that modestly bear this name on their façade and where one can obviously have some tea or cake, and also, not so obviously, a beer (to be fetched by the waiter from somewhere in the back, behind doors or curtains). As a cafetaria is usually subdivided into compartments, clients are condemned to isolation by curtains or partitions which is not very beneficial for social contact. Then there is the alimentation, a plain grocery shop where the usual soap, sugar and cigarettes are sold. If customers do not mind standing up, they can finish the drinks they bought in situ. They will have to put up with people walking in and out to purchase groceries though, which does not 
encourage anyone to hang around for a good while. And finally there are, without any visual sign or billboard at all, the cabarets, private dwellings where home-brewed alcohol and sexual services are sold by the owner, a single woman usually. However sleepy and tedious Butembo might appear at first glance, it gets lively in these cabarets.

Clearly, the places that are largely announced and advertised, are also the places where one likes to be seen. Being able to afford a beer in a place like Auberge is considered a sign of social advancement. These fancy places have huge restaurants and large lawns where guests can sit under the trees too, so they can keep an eye on each other. Those who wish to remain completely out of sight, on the other hand, go to the cabarets. And in all these places, seen and unseen, the presence of women is abundant.

\section{THE HOMELY CABARET}

So a cabaret is a private dwelling in which a single woman offers alcoholic beverages and sexual services alike. In many cases, she rents the place, often a simple mud-and-stick house that consists of two rooms only, a living room and a bedroom. During cabaret hours, these private spaces turn public. The living room seats the customers, it is modestly furnished with some sofas, a coffee table and a cupboard, just as any ordinary Bubolais living room is. The private bedroom of the cabaret owner turns into a chambre de tolérance, the room where things are tolerated. The cabaret owner can withdraw to this room with a client, or she can rent it by the hour to customers who take along a (temporary) lover of their choice. The chambre is the core of a cabaret, and a cabaret owner who fails to provide one will fail to lure customers. However, a visit to the chambre de tolérance is by no means compulsory, many clients just come to enjoy a drink and meet kindred spirits. A cabaret stands on a compound or parcelle which it shares with other dwellings, and often these too are cabarets. A few trees, often banana trees, shadow the inner yard. The whole parcelle is fenced off by bamboo canes, or by cypresses, a relic from colonial times. A hole in the fence shows where the entry is.

Outwardly, nothing discerns a cabaret from an ordinary house. There is no visual sign that displays the function of the place, nor music playing to lure passers-by, so it is a place where one is taken to by someone who is familiar with it. It is what happens inside that makes the difference, but this indoors bustle is carefully closed off by a curtain. And even inside, as 
we will see later, the sex-for-money activities are never discussed openly, but in hidden ways. Women will always talk about a 'husband' (mari) when they refer to a client. And a man, in his turn, will say he has seduced (in Swahili: nilitrezê) when he has passed some time in the chambre de tolérance, without ever mentioning the money he has just spent. In short, these cabarets submerge in a sphere of secrecy and concealment. Moreover, it is quite dark inside the places too, even during the day, as the windows of these mud-and-stick houses are usually very tiny, and as the city is not electrified, cabarets are only dimly lit by a faint candle or paraffin light. However, despite all these confidentiality measures - the silence, the lack of signage, the curtain, the dimmed light-every Bubolais knows what is going on inside. So strangely, although these private spaces turn public in the eyes of the cabaret owner (accommodating known but also unknown customers in her home), they turn into spaces of intimacy and privacy in the eyes of the customers. The private sphere the customers believe they enjoy, is merely an illusion however, as what happens in there is spread throughout the entire city.

THE WORKINGS OF A CABARET

There are hundreds of cabarets throughout the city, so to local women, running a cabaret seems an easy but significant way to earn an income. To start up a cabaret indeed requires no investment other than a bottle of mbandule, a homemade distilled alcoholic beverage. There is no need for additional expenses for accommodation, since clients are received in the private home that is rented and furnished anyway. Some expertise is advisable to become a fully-fledged cabaret owner, and this is usually acquired through a longstanding apprenticeship. Ghissy, for instance, learned how to treat customers in the appropriate way at Marie-Gorette's, an elderly woman who has been in business for over 20 years, and who is also the landlord of the cabaret that Ghissy currently rents. Ghissy and Marie-Gorette go back a long time, as the former explains: 'well, I have known Gorette since ages. She is as my big sis actually. I just lived at her place doing nothing in particular. I was the girl that helped her to ... to do the odd jobs, get her some water, and stuff like that' (Ghissy 2009 int.). Off the record, Ghissy added that Gorette also taught her how to comfort men, satisfy their needs, and make sure they show up again in the near future. An apprentice one day becomes master, and has apprentices of her own, just as Ghissy has today. 
Yaya is a cabaret woman who is very popular among girls, who attend her place in droves. The popularity of the girls in turn guarantees that Yaya's business runs smoothly. Once these apprentice girls have the knack of it, they hop from one cabaret to another every few months, and stick around until the clients yearn for some new faces. A change of girls can give a cabaret a boost, as witnessed by Charlie after she engaged two young beautiful girls, freshly arrived in the métier. A client however might follow a girl as well; if she managed to bind him to her, he will go to whatever cabaret she goes.

As said, the chambre de tolérance is at the core of the business. As for the interior, there is a wide range of variations, from plushy to bare. At times, the chambre de tolérance is lavishly garnished and stands in stark contrast to the rest of the mud-and-stick house. In Ghissy's room, for instance, tiny as it is, stands a huge kitschy white iron double bed, covered with pink satin bedding, finished with golden galloons. Shiny posters cover the mud walls all round, and they picture luxurious interiors in Western style, and foamy waves breaking on palmed beaches. The ceiling is decorated with abundant voile in pale colours. Underneath the bed, Ghissy keeps her clothes and money in a couple of suitcases. The entire room is scarcely lit by a miniscule window that has no windowpane, but is closed off with mosquito netting, as usual. A small bedside table finishes the room off, and on top of it lie some candles and condoms. Ghissy is amongst the cabaret ladies who do fairly well, and the interiors of the chambre de tolérance of her colleagues look far less sumptuous. Mama Jiresse's one, for instance, corresponds more to the average Bubolais bedroom interior. She, for one thing, sleeps in a single bed, and even this narrow bed barely fits into her room. The bed itself is made of unfinished wood and modestly garnished with some cloth. The walls are bare, except for a small wooden crucifix. Her belongings too, she shoves under her bed in suitcases. It is pitch-black inside.

Since Bubolais as a rule live in cramped conditions, the chambre de tolérance leads out onto the living room, and only a thin curtain separates the two. As a consequence, guests having a drink in the sitting area easily overhear what is going on in the next room. When one afternoon, I entered Soki's cabaret, she had just rented her room out to a couple of lovers. Seated in the living room, I could hear the groaning of the guests. Soki was rather embarrassed, urged them to keep it low, and finally fetched a radio and turned the volume up high to smother their sounds. The fine, often transparent, and by no means soundproof curtain, epitomises the social practices of the cabaret. Although much is done to conceal what happens, these efforts are fruitless, and 
everyone actually knows. Moreover, as the case of the curtain shows, even the concealments are mere make-believes, pretending to cover something up while they cannot possibly do so. Behaviour in cabarets is ambiguous throughout, and the denials turn ludicrous the more persistent they get. One day while I was at mama Kibonge's, a client asked her in the local language Kinande what exactly I was doing at her place. She explained about my research, to which he added, 'well, and does she know you sleep with us?' Mama Kibonge spiritedly replied 'take care, she might have you all arrested for paying me far too little'. It took quite some time to get used to women denying things happening, while they were happening right under our very noses. Gradually, I learned to speak in metaphors as well, and the more I excelled at it, the more the women revealed about their doings.

\section{OCAL ECONOMIES OF L OVE}

The 'entanglement of sexual behaviour and affective relations', as Lynn Thomas and Jennifer Cole (2009:4) put it, is a topic which is very understudied in African areas, and 'contemporary discourses, sentiments, and practices of love are the product of complex historical processes and intersections' that need to be analysed more closely. In Western thought, blending money with love is usually considered to be morally reprehensible. A woman or a man who picks out a well-off partner for profitable ends, is often looked down upon. In Congo however, making such a suitable choice is a sign of intelligence, and the capacity to haul in a smart catch is genuinely applauded. As Joseph Trapido (2010: 121) stated, '[i]n liberal, Western European ideology such a confluence of love and money appears blatantly insincere, or at least contradictory', whereas in Kinshasa, 'there is no systematic ideological opposition between love and money'. Jennifer Cole (2009: 1111 ) adds that 'popular Western ideologies of love ... ignore how emotions and materiality might, in fact, be deeply intertwined'.

Prostitution, on the other hand, is a topic that is widely studied, but the additional entanglement of sex and cash does not simplify its analysis. It is not hard to understand why African women turn to sex labour to secure their livelihoods, particularly since the profession does not bear a derogatory label. Since time immemorial, cleverly handled sexual liaisons allow provision of a substantial income. In 193 os Nairobi for instance, free women were able to buy property, and were considered as the new 'petite bourgeoisie' (Rodriguez- 
Torres 1999: 118). Also to Kinshasa's ndumba in the beginning of the 1960s, the métier was a valuable alternative, allowing women to climb up socially. As La Fontaine (1974: 111 ) put it, 'it offers a strategy for the economic support of women, which is an alternative to marriage and, given the lack of educational background and the general competition for employment it is a more profitable strategy than trade or wagelabour'. To differentiate prostitution as a Western concept from the sexin-exchange-of-money practices in Africa, scholars often indicate the possibility to choose the sexual partner, the longer span of time the sexual relationship lasts, and the courtship it involves. As observed among the sex workers such as the passenger women of Papua New Guinea (Wardlow 2004) or the sanky pankys and jineteras or jineteros of the Dominican Republic and Cuba respectively (Cabezas 2004), 'sex workers' often prefer to avoid the harsh sounding label of prostitution. Cabaret women too set great store by distinguishing themselves from the wambaraga of the city, the women who scour bars looking for clients with whom they spent just a couple of hours in a hotel room in exchange for some cash. They stress that they are 'decent' women, and that they take proper care of their 'husbands'. Moreover, all the cabaret owners that were interviewed make an acceptable living, especially as compared with the income of an average Bubolais. And to a few among them, running a cabaret plainly meant big business, and it helped them to climb up socially at a steep pace, and buy a parcelle with a brick house, the utter sign of prestige.

H O M E L Y C O M O R T S

One afternoon in Nyembo's cabaret, a typical conversation arises between her and a client. 'You know I don't come here just for drinks, don't you?', the client says to Nyembo, adding 'I come here because I love you'. Nyembo just chuckles. 'Why don't you serve me some food?' the client then suggests. 'I don't have any', Nyembo answers, 'Why don't you buy me some beans and meat?' The client slips her some cash which she promptly puts in her pocket. Food is not only an essential service of cabarets, but also an important issue while courting, as it is a metaphor for sexual relations. As the above conversation shows, buying food is a prerequisite for access to other services, and Nyembo playfully manipulated this knowledge and received what she wanted. Offerings such as manioc flour, palm oil or kidney beans enable access to the chambre de tolérance, and thereby to the cabaret 
owner's body. Comestibles are not only exchanged in reality, cabaret women also borrow from the gastronomic lexicon to playfully refer to sexual pleasure.

Food-related metaphors are commonplace in Congolese languages, for instance in Lingala. In the lyrics of musicians, 'the verb kolia - to eat-is widely used as a direct synonym for sex' and is a recurrent issue, as Joseph Trapido (2010: 137) reveals. In Kinande too, sexual intercourse is linguistically associated with eating, as erirya means 'to eat', and is at the same time used to refer to 'having sexual intercourse'. Moreover, 'satisfaction from sexual intercourse is termed, as is that from eating, eryuguta (verb)' (Vwakyanakazi 1987: 6o8). Talking about and demanding nourishment, is a roundabout way for both parties involved to reach an agreement about services to come. On the other hand, conversations about food also come in handy to turn someone down. As mama Jiresse explained: 'to the one I don't like, I say "you never bring any of the food items I asked you for", and that's enough for him to understand I don't want him' (Jiresse 2009 int.). A failure to bring food along, is a legitimate basis upon which to dismiss (undesired) clients.

To establish customers' relations with the clients they do want, cabaret owners make them feel at home, and act somewhat like a spouse, talking over her daily chores, and creating a cosy and homely atmosphere. The meals are part of the homely services that cabaret owners and their employees supply to their guests, before they might proceed with the more physical arrangements. Apart from serving dinners and breakfasts, the customer's clothes are washed, his body scrubbed, and his selfesteem boosted. Pampering is just part of the job. The major advantage of these 'comforts of home' (White 1990), is that clients tend to return to wherever they were warmly welcomed and received, because the appreciation of a cabaret owner depends largely upon these household tasks. Besides this, affection is a prerequisite to build up steady client relations too. To spoil guests and make them feel self-confident and strong, is essential, according to cabaret owners. Part of this act is to give him the feeling that he conquered her, not just through payment, but that he succeeded in winning her heart, and that she gave in to his irresistible charm. The preliminary discussion about the money he will spend, is never mentioned again afterwards. Moreover, a cabaret owner creates the illusion of sexual loyalty, makes the client feel as if he is the only one who enjoys her attention. It is an important asset too, and turns men into dedicated clients.

The women themselves state a cabaret setting is advantageous for clients, as they know the women they are dealing with. From girls they 
meet in a bar, on the other hand, it is hard to trace the past. The main problem cabaret women discern with 'that kind of wambaraga', is that they remain anonymous, and there is no way clients will get to know them thoroughly. In the context of the political unsteadiness of the Kivu provinces, to be well acquainted matters, and Bubolais generally look at unknown persons with suspicion.

As said, cabaret women like to differentiate themselves from the local wambaraga, they state they have more to offer. They take their clients to their chambre de tolérance, either for a brief encounter, or for the entire night. Spending an entire night in the chambre is considered a privilege; not only is it paid for accordingly, but it is a right granted exclusively to the clients that the cabaret owner genuinely likes. Consequently, men sleeping over make themselves at home, and act accordingly. The threshold between public and private is constantly crossed, and the additional homely services - the cooking, the washing of clothes and bodies - add to the blurring of both spheres' edges. In any event, a protracted stay in the chambre is an affectionate matter, and the accidental mari starts behaving as a lifelong husband.

It is important here, though, to distinguish the cabaret owners from the deuxième bureau, or long-standing mistress of a Congolese man. With the latter companion, a man builds up a steady relationship and (eventually) starts a family too, besides the one he has with his legally wedded wife, and this mistress is generally acknowledged and accepted in his circle of friends and relatives. To Katrien Pype (2008: 337), the relations with a deuxième bureau are 'modern urban polygamous relationships and denote longstanding extra-marital sexual liaisons with women past adolescence'. The more such mistresses a man can afford to support, the more his social status rises. The relationship with a cabaret owner, however, is not shown off, but more discreetly consumed.

\section{THE POWER OF LANGUAGE}

Language is an important asset in this world of make-believe in a cabaret. As seen, cabarets are veiled by a sense of secrecy that suits a secluded city such as Butembo and its inhabitants who crave for discretion at all times (Geenen 2012). Charles Piot (1993) stresses the need to focus on the everyday while analysing the role of secrecy, and not merely on the ritual as most scholarly literature on the issue does. As such, a focus upon the linguistic transactions, that is upon the daily words captured in cabarets, reveals a 'hidden transcript' (MacGaffey \& Bazenguissa- 
Nanga 2000: 160). A cabaret woman provides services that a client needs, but inevitably this need has to be expressed and the desired transactions defined before anything can possibly happen. Whatever will be performed inside the chambre de tolérance is never discussed explicitly, but always in indirect ways. Language is a most suitable device to mask what is going on. As Fabian (2003: 491) puts it, 'secrecy is not the absence of communication, but a certain kind of communication'. Within cabaret doors, guests communicate in metaphors whenever it concerns the physical aspect. Sexual intercourse is talked about in a roundabout way, alluding to but never directly discussing the event in question' (Piot 1993: 353). We have already seen that food often suits as a metaphor to refer to sexual intercourse. Similar to what La Fontaine (1974: 109-10) had observed in the milieu of the free women in 1960 Kinshasa, the selling and buying is never mentioned, as these concepts do not suit a genuine relationship, or the kind of affectionate relation the client likes to believe he is involved in.

To make sure the client has a homely feeling, he is never referred to as 'a client', but always as un mari, 'a husband'. What both parties want, of course, differs. To put it very bluntly: he wants sex, and she wants money. The flattering is a way to achieve these ends, it is the pitch that leads to the sales agreement. Make-believe is an essential part of the deal, the man has to have the idea that he has conquered a woman by his own means, that he owes it all to his seductive skills. She knows, and she pretends. She playfully steps into this staged setting. She obstinately calls her client her husband, flatters him and keeps silent about other clients. It all demands some ingenuity, obviously. In the words of mama Jiresse, when asked how she handles her husbands, she replied 'dawacheza!', I will manipulate them, in order to make them think they are the only ones, and that there is no room for unfaithfulness in the 'relationship' (Jiresse 2009 int.). Of course, it is all make-believe, and clients are aware that the money is a decisive factor during the transaction.

In addition, although cabaret women flatteringly talk about their clients as maris, they do not hesitate to become tough with them whenever they fail to bring any food or cash. In this case, she will firmly defend her rights. It is a major drawback, indeed, to this act-as-if-at-home performance proper to cabarets, that customers tend to take these comforts for granted in the long run, and fail to pay the bill. Joséphine discerns a repeated pattern in the visits from clients to her cabaret. The very first time they come to her place, she states, men are very generous, and without much ado leave her some money and food. But in the long run, after repeated encounters during which they were treated with 
great devotion as 'a good wife' would do, men start taking it all for granted, and 'forget' to pay before they leave (Joséphine 2009 int.). It is reminiscent of the blurry line of the colonial whites with their housekeepers or ménagères during colonial times (Hunt 1999; Lauro 2005).

A MAGIC POTION OF LOVE

Food and sex are not only crossed linguistically, as we have seen above, but also magically. Whenever a Bubolais woman-cabaret women and wambaraga included - wants to bind a lover to her or to bring him to his knees, she relies upon the expertise of a féticheur or traditional healer to make her dreams come true. Sometimes the prescription of the féticheur involves a particular magical stew with odd ingredients the woman has to prepare and serve to her target in order to obtain the desired effect. For instance, the woman is suggested to put, apart from meat and vegetables, pieces of hair and nails into the casserole, or the water that she has used to wash her genitals (Vwakyanakazi 1987: 605). The sex workers themselves drink a homemade brew as advised by the féticheur too, whenever they yearn to boost their sex appeal or suli, and consequently their business. As a matter of fact, free women throughout Congo have the reputation to have recourse to love medicines, and in Kinshasa they are nicknamed 'bamela milangi', those-whodrink-magic-potions (Vangu Ngimbi 1997: 130). The result desired by a visit to the feticheur, however, can either be positive or negative, that is to achieve a goal (better looks), or to prevent someone else from achieving their goals (destroy a good running business). The main trigger in the latter cases is envy, or eritsuro in the local language Kinande. Nyembo explained how the success of her cabaret conjured jealousy among competing women. One of them had called upon a féticheur to break this success, and the latter had given her some fetishes (ngiri ngiri) to hang about Nyembo's place. When after two weeks, the woman saw no decline in Nyembo's clientele, she got remorseful and confessed her mischief to Nyembo. In the case of mama Julie, the sorcery to break her success was said to have turned out to be fatal. The magical stew involved contained poison, believed by the Congolese to be a common practice in their country (Verhaegen 1990: 1 17), and she died a few days after consumption. As justice operates randomly and judges are easy to corrupt, there is a sense of lawlessness throughout Butembo, and similar actions of vengeance usually remain unpunished. 
Cabarets are gendered spaces, exclusively run by (single) women, without the assistance of any male companion. Most customers are male, but nevertheless, it is women who wear the trousers. Running a cabaret provides a substantial income to numerous Bubolaises or female citizens, and consequently to the many relatives who depend upon them. Women do occasionally visit a cabaret as a client, but rarely do so on their own. A group of young girls might come along to drink out of sight of their parents, or to experience their first sexual experimentations in the chambre, as spaces that offer some privacy are hardly found at home. When it concerns adult female clients, these are often mistresses who are taken along by their lovers, and in rare cases a husband takes his wife. Bubolaises take a dim view of women going to cabarets. They prefer to meet up at alimentations or cafetarias which they consider to be more suitable for dignified women. Some men too are not keen on the drunken scenes in cabarets, but to those who live on the outskirts of the city, there is little or no alternative. Butembo goes through bursts of random killings of innocent people, and this insurgence usually begins in the outskirts of the city, as the surrounding hills are hideouts to various rebellious groups. In June 2009 for instance, Butembo passed through such a period of turmoil, and it lasted for about six weeks. There had already been some killings in the weeks before, but only slightly more than usual, when suddenly the violence culminated the night of 6-7 June, which was particularly rough. Numerous dwellings were looted that night, and passers-by were robbed. Three young Bubolais were brutally killed too, two of them inside their homes, but it was especially the corpse of the young girl found the morning after, displayed on the main road, her throat slit open, that sent a shockwave through Bubolais society. As commented on a website next day, 'Butembo is no longer a city where one has fun on Saturday evenings. Bubolais are compelled to lock themselves in after nightfall' (Benilubero, 8·6.2009). As such, during similar periods of insecurity, a visit to a cabaret is the safest option for those wanting to meet up with others, as they can be found everywhere, so there is no need to venture too far in the streets to reach one.

There is a pattern to be discerned in the motives that made the women decide to start running a cabaret. The need for an income was, obviously, a primary trigger, and as we have seen, to open up a cabaret requires less investment than, say, selling second-hand shoes. All cabaret owners confirmed they earn more than Bubolais who have a 
regular job. Louise, who is a trained nurse, changed professions when she found out she could earn more running a cabaret than from working in a dispensary. By way of comparison, an employee engaged in a boutique earns between US $\$ 10$ and US\$2O a month, a trained nurse earns close to US\$120 a month. Cabaret women state they make US $\$ 15^{\circ}-400$ a month. Ghissy, who combines her job running a cabaret with the smuggling of mbandule which she distributes to colleague cabaret owners, defined her income as 'a great big deal' (Ghissy 2008 int.).

But what were their personal backgrounds when the decision was taken? What was their frame of mind when they launched themselves into the business? It is striking to see that almost all of the women that were interviewed, had one experience in common: they were deceived in love matters. Former lovers/partners/husbands were, most informants admitted, unfaithful and irresponsible individuals. All of Joséphine's former partners were fooling around, Ghissy's ex 'azalaki farceur' [was a joke] (Ghissy 2009 int.), Marie Kayiri's husband meant nothing but 'disorder' (Marie Kayiri 2009 int.), Nono's was a lady's man besides being a drug addict, and Kavira's ex-partner hung around with far too many wambaraga throughout their relationship. The women were subsequently left to their own devices by their former partners, and they often also left them with offspring to feed. Most informants had given birth, but there was no sign of fathers anywhere. Mama Kibonge, for instance, has four children with four different men, and none of them cared to educate or finance their progeniture. Sometimes the absence of a partner has nothing to do with behaving badly or escaping responsibilities. Nyembo's husband, for instance, who is a soldier, was transferred, and mama Jiresse was widowed by hers after a long bout of illness. Still, the majority of the cabaret women share a profound deception in matters of love.

Some state their profession had empowered them. Whereas they were formerly turned down by lovers, now the time had come for them to deceive men, as they have the choice to refuse any potential client who does not please them enough. This choosiness increases their self-esteem. The practices had shaped the women's agency, and they are proud they are economically independent on top of that, and enjoy their autonomy. This is also illustrated by the conditional sexual intercourse. The spread of HIV has raised a safe-sex awareness in the métier, both among cabaret women and among their clients. Condoms are easily available in Butembo, but women often prefer to use female condoms to keep complete control over the safety of their short-term intimate relations. As Joséphine stated, she immediately pays her client 
back when it turns out that he prefers to have unprotected intercourse. All informants equally insisted that they will not accept unsafe encounters, under any circumstances. Most of the clientele too, as informants subscribed, are fully aware of the risks and take precautions. Still, less vigilant customers exist as well. They sometimes mentally blackmail the women who insist on the use of a condom, stating that only ngoshingoshi, skin to skin intercourse, equals real love, and that the interference of a condom discloses the pretending.

The aspirations of the cabaret women are identical: they all firmly resolve to quit the business one day. Setting up a cabaret is a provisional occupation to enhance one's social status, a way to improve living conditions and to lead a life according to higher standards. But it is supposed to be a temporary measure, and all informants expressed the desire to strike out on a new course one day. To be financially prepared for the future change of direction, the earned income is put aside when it is within the bounds of possibility. Ghissy, as said, succeeded in buying a compound with a brick house through the savings she had been accumulating since she founded her business. Some women wish to invest in education as well. Joséphine has just completed the first year of business school, as she wants to launch a business in (second-hand) shoes. And finally, aspirations are passed on to offspring and siblings too. The daughter of Suza, who is a 22-year-old girl working at Yaya's, lives at her grandparents' house, as Suza has no time to care for her. However, Suza wishes that her eight-year-old girl might one day become a nurse, and pays her school fees. Nono, likewise, pays for the education of her younger brother, who is a law student at the local university UOR (Université Officielle de Ruwenzori).

Their aspirations are quite uniform on an emotional level as well. Except for Ghissy, none of the informants expressed the wish to get married (again) one day. The prospect of carrying the baby of a well-todo client, on the other hand, is more appealing and yields considerable enthusiasm. By and large though, Butembo's cabaret women claimed to have been too deceived in matters of love to give it another try.

THE SIGNIFICANCE OF THE CABARETS

Cabarets are places where single women earn an income. Places where people enjoy a drink and meet potential sexual partners. They are also places that lovers retreat to in search of intimacy. This is what cabarets are known and notorious, despised and praised for. And yet, there is 
more to it than meets the eye. Even though cabarets' omnipresence contrasts keenly with their lack of visibility, it certainly fits in with their outstanding significance. Their major importance is felt in many ways, as their functions are multiple. Cabarets are places where movements are triggered and blow over. Accordingly, they are spaces of various kinds of diffusion: spaces where information is spread, money circulated, contacts disseminated. Spaces one enters in order to get attuned to the city, to get a grip on its dynamics, and to get in touch with its undersurface.

The first movement that crosses the cabarets, is liquid capital. Bubolais generally complain that in their city, the financial flows of the better-off businessmen the city is renowned for, do not impinge upon them, as they rarely supply themselves at local markets or neighbourhood shops. Cabarets, however, are sites where this kind of money does trickle in, as the better-offs too, patronise these places, and as such provide a supplementary income to their owners. Consequently, through spending their earnings in local shops and markets, cabaret women inject this flow of cash into Bubolais society (Kakule Kaparay 2004: 71).

News and information are spread in cabarets too, and it is often the very most up-to-the-minute information available. Many clients admit to frequenting their favourite cabarets on a daily basis to keep posted, and to sound out what happens in their city. In the tumultuous political context of eastern Congo, being well informed can be a matter of life or death. On top of that, the city authorities count upon cabaret owners to give away 'armed men' (des mains armées) whenever they show up in their places, as Nyembo admitted (Nyembo 2009 int.). A laudatory article about a cabaret woman who had helped the authorities to catch a FARDC soldier turned bandit, appeared in the local media, illustrating what a considerable value they are to society. Job opportunities too are propagated through cabarets, and the jobless or recent immigrants go there in order to get employment. People also genuinely enjoy the conversations with the other clients they meet there. The bits of news are often hot off the presses and the sources are reliable. It had often surprised me that even if cabaret women themselves were often rather tight-lipped, their clients generally turned out to be most loquacious informants. In a strange way, the enclosed environment of the cabaret made them talkative. Unfortunately, when a considerable amount of mbandule was consumed, the conversations often ended in nonsensical stories.

Cabarets are unruly spaces. They are illegal and officially non-existent, but taxes are collected on each of their separate activities, and some of its 
services are forbidden. In the view of a city official, Gilbert, cabarets 'do not exist' so there is no need to work out a policy concerning these places. What is more, it is said on the record that they will be shut down 'if such places should exist' (Gilbert 2009 int.). So the position of the authorities towards the cabaret business is ambiguous, to say the least. They are obviously acquainted with the businesses-more than once I ran into city officials in a cabaret-but they turn a blind eye. More than that, the city authorities expect cabaret owners to report the presence of armed individuals in their place. Also, cabaret women did complain to me about having to pay rates; in these cases, it concerned individual civil servants who tried to complement their income through devious means, and asked for hush money. And even if cabarets are officially non-existent, and thus cannot possibly be forbidden, what is going on inside cabarets can be illicit, and punished. For one thing, simplifying a sexual encounter by offering a private space is an infraction to local law, and can be fined accordingly. In short, the legal status of cabaret women is equivocal, to say the least.

Many Bubolais confirmed the importance of this underground web of cabarets. Numerous informants expressed the need to pass by 'their' cabaret on a daily basis, subscribing to the major significance these places have in their lives. As one habitué expressed, he visits a cabaret 'afin de m'équilibrer' to recover his balance (Jack 2009 int.). Bubolais find it easy to satisfy this need, as cabarets are to be found virtually everywhere. But as noted earlier, they are hard to find unless one is taken along by a regular. So strangely, although cabarets are places of integration, they are hard to access, which of course does not favour integration. On top of that, newcomers go there to get attuned to the city, but they are thoroughly screened before they get accepted. As a labour inspector and regular named Bonaventure explained, it is of the utmost importance to find out where the newcomer originates from. Bonaventure is particularly on his guard when a newcomer speaks with an accent from the Rutshuru area, he adds, as 'he might be connected to the Interahamwe rebellion' (Bonaventure 2009 int.). In an insecure and dangerous environment such as Butembo, people go to their cabarets to be kept posted.

As such, the deep intertwining of these places with the city's social fabric is a consequence of the danger the Bubolais face while walking outside after nightfall. Whenever there are concerts or weddings, these end at about 6:00 pm to allow the guests to reach their homes safely. The city centre itself is usually cleared of thugs, so for those living right there, the alimentations and hotels are within easy and 
secure reach. Cabarets allow people to safely go to a place and relax, to chat with peers and to keep abreast of current events.

\section{R E F E R E N C E S}

Biaya, T.K. 1996. 'La culture urbaine dans les arts populaires d'Afrique : analyse de l'ambiance zairoise', Canadian Journal of African Studies/Revue Canadienne des Études Africaines 26, 2: 337-48.

Cabezas, A.L. 2004. 'Between love and money: sex, tourism, and citizenship in Cuba and the Dominican Republic', Signs: Journal of Women in Culture and Society 29, 4: 987-1015.

Cole, J. 20o9. 'Love, money, and economics of intimacy in Tamatave, Madagascar', in J. Cole \& L. M. Thomas, eds. Love in Africa. Chicago, IL: University of Chicago Press.

Emizet, K. 2003. 'Conflict in the Democratic Republic of Congo: a mosaic of insurgent groups', International Journal on World Peace 10, 3: 51-80.

Fabian, J. 2003. 'Forgetful remembering: a colonial life in the Congo', Africa: Journal of the International African Institute 73, 4: 489-504.

Fardon, R., ed. 199o. Localizing Strategies : regional traditions of ethnographic writing. Edinburgh: Scottish Academic Press; Washington: Smithsonian Institution Press.

Geenen, S. 2010. 'The gold trade in Butembo', in J. Cuvelier, ed. The Complexity of Resource Governance in a Context of State Fragility: the case of eastern DRC. London: International Alert.

Geenen, K. 2012. 'How people of Butembo (RDC) were chosen to embody "the New Congo": or what the appearance of a poster in a city's public places can teach about its social tissue', International Journal of Urban and Regional Research 36, 3: 448-61.

Hoffman, D. 2003. 'Frontline anthropology: research in a time of war', Anthropology Today 19, 3: 912.

Hunt, N.R. 1999. 'STDs, suffering, and their derivatives in Congo/Zaire: notes toward an historical ethnography of disease', in Ch. Becker, J.P. Dozon, Ch. Obbo \& M. Touré, eds. Vivre et penser le sida en Afrique/Experiencing and Understanding AIDS in Africa. Paris: Codesria, IRD, Karthala, $111-31$.

Jackson, S. 2002. 'Making a killing: criminality and coping in the Kivu War Economy', Review of African Political Economy 93/94: 517-36.

Jackson, S. 2006. 'Sons of which soil? The language and politics of autochthony in Eastern D.R. Congo', African Studies Review 49, 2: 95-123.

Jourdan, L. 2005. 'Congo. Recherche ethnographique dans une "drôle de guerre"', Civilisations, LIV (1-2) - Expériences de recherché en République démocratique du Congo: 179-90.

Kakule Kaparay, Ch. 2004. 'La circulation monétaire dans les villes de Beni et de Butembo', Parcours et Initiatives. Revue Interdisciplinaire du Graben 2, Avril: 69-74.

La Fontaine, J.S. 1974. 'The free women of Kinshasa : prostitution in a city in Zaïre', in L. Ph. Mair \& J. Davis, eds. Choice and Change. Essays in honour of Lucy Mair. London: University of London, The Athlone Press.

Lauro, A. 2005. Coloniaux, Ménagères et Prostituées au Congo Belge (1885-1930). Loverval: Éditions Labor.

MacGaffey, J. 1987. Entrepreneurs and Parasites: the struggle for indigenous capitalism in Zaire. Cambridge: Cambridge University Press.

MacGaffey, J. \& R. Bazenguissa-Ganga. 2000. Congo-Paris. Transnational Traders on the Margins of the Law. African Issues. The International African Institute in association with Oxford, James Currey and Indiana, Indiana University Press.

Piot, Ch. 1993. 'Secrecy, Ambiguity, and the Everyday in Kabre Culture', American Anthropologist 95, 2: $353-70$.

Pype, K. 2008. 'The Making of the Pentecostal Melodrama. Mimesis, Agency and Power in Kinshasa's Media World (DR Congo)'. University of Leuven, PhD dissertation.

Raeymaekers, T. 2007. 'The power of protection, Governance and transborder trade on the CongoUgandan frontier'. Ghent University, PhD dissertation.

Raeymaekers, T. 2014. Violent Capitalism and Hybrid Identity in the Eastern Congo: power to the margins. Cambridge: Cambridge University Press.

Reyntjens, F. 2009. The Great African War: Congo and regional geopolitics, 1996-20o6. Cambridge: Cambridge University Press. 
Rodriguez-Torres, D. 1999. 'La libre enterprise au feminin. Une typologie de la prostitution à Nairobi, Kenya', in D. de Lame \& Ch. Zabus, eds. Changements au Féminin en Afrique Noire. Anthropologie et Littérature. Volume I : Anthropologie. Paris: L'Harmattan.

Titeca, K. 2009. The Changing Cross-Border Trade Dynamics between north-western Uganda, north-eastern Congo and southern Sudan. Crisis States Working Papers Series No. 2, Working Paper no. 63Cities and Fragile States. London: Crisis States Research Centre.

Thomas, L.M. \& J. Cole. 20o9. 'Thinking through love in Africa', in J. Cole \& L.M. Thomas, eds. Love in Africa. Chicago, IL: University of Chicago Press.

Trapido, J. 2010. 'Love and money in Kinois popular music', Journal of African Cultural Studies 22, 2: $121-44$.

Vangu Ngimbi, I. 1997. Jeunesse, Funérailles et Contestation Socio-Politique en Afrique. (Le cas de l'ex-Zaïre). Paris: L'Harmattan.

Verhaegen, B. 1990. Femmes Zaïroises de Kisangani. Combats pour la Survie. Paris: L’Harmattan.

Vlassenroot, K. \& T. Raeymaekers. 2004. Conflict and Social Transformation in Eastern DR Congo. Gent: Academia Press.

Vwakyanakazi, M. 1982. 'African Traders in Butembo, Eastern Zaïre (1960-1980). A case study of informal entrepreneurship in a cultural context of Central Africa'. University of WisconsinMadison, $\mathrm{PhD}$ dissertation.

Vwakyanakazi, M. 1987. 'Good things to think but not to eat: love management among the Nande in eastern Zaïre', Africa. Rivista trimestrale di studi e documentazione dell'Instituto Italo-Africano Anno XLII, 4: 600-12.

Vwakyanakazi, M. 1991. 'Import and export in the second economy in North Kivu', in J. MacGaffey, ed. The Real Economy of Zaire. The contribution of smuggling and other unofficial activities to national wealth. Philadelphia, PA: University of Pennsylvania Press.

Wardlow, H. 2004. 'Anger, economy, and female agency: problematizing "prostitution" and "sex work" among the Huli of Papua New Guinea', Signs 29, 4: 101 7-40.

White, L. 1990. The Comforts of Home: prostitution in colonial Nairobi. Chicago, IL: The University of Chicago Press.

\section{Interviews}

Interviews were conducted in Swahili, Lingala or French, and translated by the author.

Bonaventure, labour inspector, Butembo, 22.6.2009.

Ghissy, cabaret owner, Butembo, 16.2.2009, 29.12.2008 and 10.2.2009.

Gilbert, city official, Butembo, 24.2.2009.

Jack Buzito, musician, Butembo, 4.1.2009.

Jiresse, cabaret owner, Butembo, 22.1.2009 and 20.8.2009.

Joséphine, cabaret owner, Butembo, 26.6.2009.

Marie Kayiri, cabaret owner, Butembo, 2.9.2009.

Nyembo, cabaret owner, Butembo, 21.1.2009.

\section{Website}

Benilubero. 2009. <www.benilubero.com>, accessed 8·6.2009. [Original text: "Butembo n'est plus une ville où l'on s'amuse le samedi soir. Les bubolais sont obligés de s'enfermer dans leurs maisons à la tombée de la nuit.”] 